
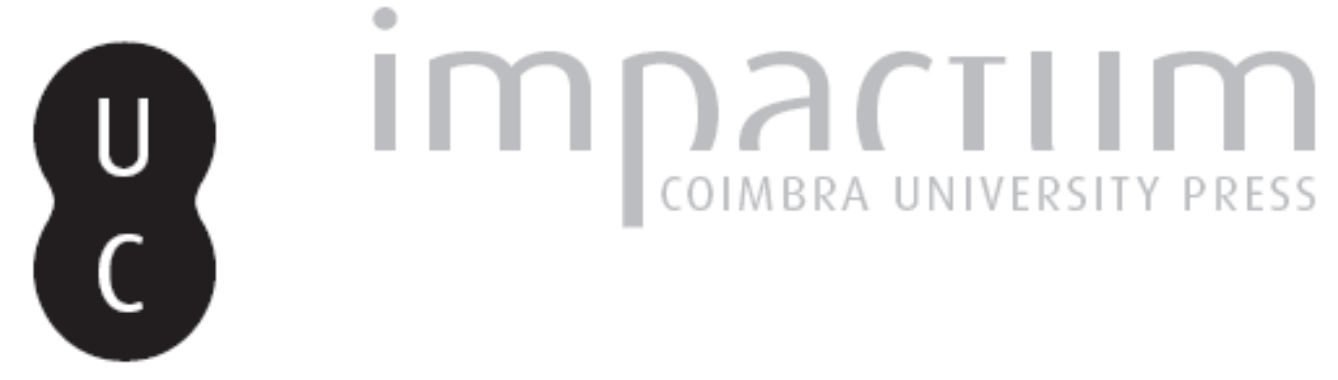

\title{
Co-creative urbanism: the production of plural evolutionary spatialities through conflicts and complicities between public and private in the streets of Hanoi, Vietnam
}
Autor(es):
Manfredini, Manfredo; Ta, Anh-Dung
Publicado por: Editorial do Departamento de Arquitetura
URL persistente:
URI:http://hdl.handle.net/10316.2/41200
DOI:
DOI:https://doi.org/10.14195/1647-8681_7_10

Accessed : $\quad$ 26-Apr-2023 10:39:52

A navegação consulta e descarregamento dos títulos inseridos nas Bibliotecas Digitais UC Digitalis, UC Pombalina e UC Impactum, pressupõem a aceitação plena e sem reservas dos Termos e Condições de Uso destas Bibliotecas Digitais, disponíveis em https://digitalis.uc.pt/pt-pt/termos.

Conforme exposto nos referidos Termos e Condições de Uso, o descarregamento de títulos de acesso restrito requer uma licença válida de autorização devendo o utilizador aceder ao(s) documento(s) a partir de um endereço de IP da instituição detentora da supramencionada licença.

Ao utilizador é apenas permitido o descarregamento para uso pessoal, pelo que o emprego do(s) título(s) descarregado(s) para outro fim, designadamente comercial, carece de autorização do respetivo autor ou editor da obra.

Na medida em que todas as obras da UC Digitalis se encontram protegidas pelo Código do Direito de Autor e Direitos Conexos e demais legislação aplicável, toda a cópia, parcial ou total, deste documento, nos casos em que é legalmente admitida, deverá conter ou fazer-se acompanhar por este aviso.

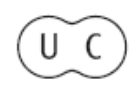




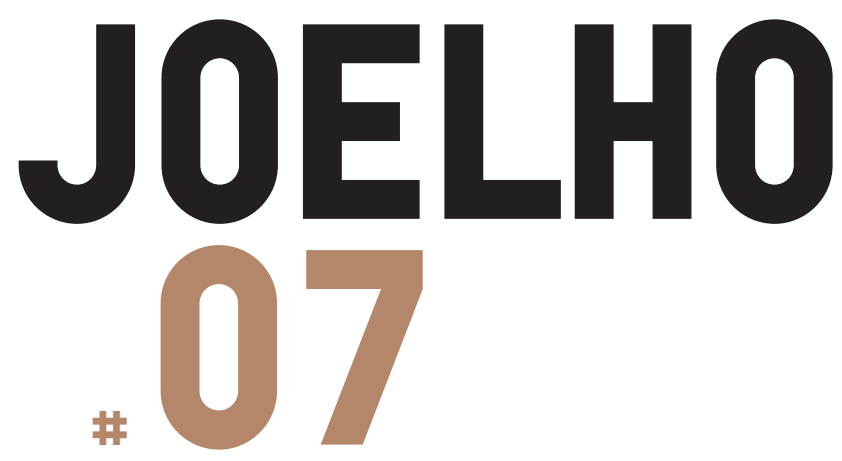

\section{LEARNING FROM MODERN UTOPIAS}

Guest Editors:

Armando Rabaça

Carlos Martins

Tim Verlaan

Hans Ibelings

Caroline Constant

Alexander Eisenschmidt

Carola Hein

Celina Kress

Alessandro Porotto

César Losada Romero

Cecilia Bischeri

and Silvia Micheli

Manfredo Manfredini and Anh-Dung Ta

Exbibition

History of Portuguese

Architecture 


$$
\text { Anh-Dung Ta }
$$

School of Architecture and

Planning, The University

of Auckland, New Zealand

\section{Co-Creative Urbanism: \\ 'T'he Production of Plural}

E.volutitionary Spatialities 'T'hrough Conflicts and Complicities

Between Public and Private in the Streets of I-Ianoi, Vietnam 
1. Creative Cities and Public Spaces: Resistance Spaces in Hanoi

One of the effects of globalization on urban governance is the prioritisation of principles of "livability" and "creativity" in policies and investments to enhance cities' competitiveness (Cooke \& Lazzeretti, 2008; de Chazal, 2010; Ho \& Douglass, 2008; Ley, 1996; Scott, 2006). Global competition has made a determinant factor the ability of cities to effectively integrate state-of-the-art infrastructure, services and products necessary to the development of service-economy and cultural sectors (EIU, 2016; Hutton, 2015; Sassen, 2011). The implementation of these policies has marked urban revitalisation strategies in major cities and has often attracted criticism for the expansion of economic elements over cultural ones and for correlated problems affecting social relationships of local communities (Baycan, 2011; Harvey, 2005; Ruth \& Franklin, 2014).

Although "creative" governance policies generally aim to produce authentic, plural places with strategies that stimulate social inclusion, participation and choralism, when the creative components are directly linked to the pursuit of economic development, their implementations tend to produce creative milieus with more-than-consumerist atmospheres (Lim, 2014; Scott, 2008, 2014; Wyly, 2013). Because of their ambition to achieve world-class quality, distinctive image (Evans, 2003; Florida, 2014; Landry, 2012; Landry \& Bianchini, 1995) and eventful character, undetermined open-system plans tend to be superseded by over-determined ones.

Public space plays a fundamental component in these strategies, since it is crucial for the definition of character of localities (Madanipour, 1999), being the most accessible repository of social, cultural and historical values (Richards \& Palmer, 2010). In most countries, the capacity to improve and renovate public spaces or create new ones has severe limitations imposed by increasing financial burdens of public administrations (Defilippis, 1997; Loukaitou-Sideris, 1993). The engagement of the private sector to offset such difficulties with public partnership or through delegation is steadily increasing, yet often results in the emergence of important privatization of public space (Hodkinson, 2012; Kärrholm, 2016; Minton, 2012).

This particularly occurs in cities with a neoliberal framework, where developers are increasingly granted political and financial power over public space. Diminished civil autonomy and lack of emancipative agencies (Barber, 1998) lead to commodification and bending of important portions of public space into privately controlled and segregated domains (Loukaitou-Sideris, 1993). This results in a loss of genuine publicness that has been described as a fatal negation of the "Right to the City" and citizens' alienation of power over the ontogenetic processes of urban production (Brenner, Marcuse, \& Mayer, 2012; Harvey, 2000).

Central-city shopping districts are prime targets of these economic improvements. In their creative transformation, local culture is often
Frontispiece (Fig. 1) Contested sidewalks in Hanoi Ancient Quarter: Quầy vỉa hè barber service. () Dat Nguyen. 
staged and spectacularized. With the creation of hyper-real realms of consumerist recreation (Richards, 2014; Zukin, 2009) these places are splintered in thoroughly themed and character-rich environments that generate strong effects of territorial transduction (Deleuze \& Guattari, 1977; Kitchin \& Dodge, 2005, 2011; Popescu, 2010). Their spaces stagger and lure, offering consolation (Zukin, 2009) and lavish compensations for the homologation, the alienation of participation agencies in the production of civil space, and for the multiple forms of social exclusions that they cause (Davis, 1992; Loukaitou-Sideris, 1993; Mitchell, 1995, 2003; Sennett, 1992; Staeheli \& Mitchell, 2006). Their domains are often dominated by large anchoring shopping and entertainment complexes that encompass multiple precincts with coordinated sequences of branded outlets (Sennett, 2006; Zukin, 2009).

The diffusion of these landscapes of more-than-consumerist practices has recently been accelerated by the extraordinary popular success of substantive festivalised precincts in rapidly developing Asian cities. The involved cultural commodification particularly affects historical cities, where the embedded material and intangible patrimonies of local society, culture and environment are at their highest. There, urban bodies of irreplaceable world heritage have been exposed to critical deterritorialisation and relational disembedding processes that may harm the development of local identity and knowledge (Lim, 2014), causing severe gentrification and, overall, compromising the resilience of local communities.

Some places pose resistance to such reterritorializing tendencies and tenaciously preserve their unique cultural and socio-spatial patrimony. These places often entail public realms with deeply rooted, idiosyncratic practices developed over centuries of informal and incremental processes. One of these places of resistance, where consolidated social and spatial rhythms frame the everyday urban experience on the basis of persistent "irregular" relations, objects and powers, is at the centre of this research.

This is a unique place, situated in the historical central district of Hanoi, where local inhabitants develop matchless sets of strategies and tactics of appropriation of their public space. Sidewalk encroachment is the most evident form of spatial practice used by local inhabitants through more-than-relational practices that involve forms of coterritorialisation operating through interactive and dynamic processes of mixed topographic and topologic composition. This place actualizes a complex set of practices that notably exemplify those which Henry Lefebvre $(1968,1991)$ defined as differential spaces (Manfredini \& Tian, 2016; Purcell, 2013). These are practices that present entangled conditions of "messy" informal processes of collaborative occupation of space. They radically disassociate themselves from those involved in the above-mentioned trend of creative transformation that, also in Hanoi, affects multiple shopping districts subject to "modernisation" plans. They are counter-models, supported by local inhabitants, both 
usual actors and transient individuals, through an extremely active and dynamic play. They illustrate how current prevailing models of urban revitalisation come up short in producing inclusive public realms for individual expression, encounters with strangers and unrestrained creative and communicative action.

These sidewalks propose an extraordinary form of co-creative loose space (Franck \& Stevens, 2007), where an apparent unpredictability of spatial organisation and use strengthens social relationality, intermingling multimodal spatial connections, and complex cultural relations. Socio-spatial systems hinged on these linear spaces seamlessly permeate adjacent buildings and open spaces through daily actualisation, reconstruction and reinterpretations based on peculiar patterns of collaborative, mutualistic and inclusionary relations.

This research explores the ambivalent and irregular conditions of these sidewalks and their context, focusing on the complex intertwining of spatialities that continuously reframe conception, production and experience. It includes a critical analysis of each distinct set of spatial practices aimed to interpret how they represent distinctive embodiments of local society and culture. The methodology of the study is designed to analyse and comparatively evaluate conditions of space (physical, socio-spatial and eidetic infrastructures) and people experiences (routinary and lived). It develops upon a theoretical construct having key reference in Henry Lefebvre's (1991a, 1991b, 1996) interpretation of the consubstantial nature of abstract and differential spatialities; John Allen's critical realism approach to multiple agencybased analysis of "social space;" and Annette Miae Kim's (2015a, 2015b) spatial-ethnography methodology, for the descriptive mapping of such a space.

\section{Emerging Problems in Vietnam's Public Space}

In the history of Vietnamese urban culture there is little evidence of a tradition of major civic institutions and spaces supporting the development of public sphere (Drummond, 2000). Historically, urban collective space has been managed by either the totalitarian or democratic systems with imposition of severe occupation of the public sphere. The effectiveness of the public sphere has been hindered in both its realms of literacy - where public opinion is mainly generated out of state-controlled media - and politics - where state activities are discussed in centrally dominated fora. From the planning perspective, the limited political agency of the public realm results from approaches to public space mainly led by functional, technological and aesthetic criteria. Plan implementations consistently result in design practice scarcely engaging with social, cultural, economic and political matters (Boudreau et al., 2015; Kim, 2015). The academic environment reflects that orientation, as results from the work of prominent Vietnamese scholars such as Trong Thuat Pham (2002) and Trung Hai Ngo (2005), who are chiefly concerned with formal and stylistic aspects. However, 
in recent years, a more critical research on Vietnamese public space and the impact of globalization and top-down governance has also emerged, from the impulse given by international scholars (Boudreau et al., 2015; Douglass \& Huang, 2007; Hornidge \& Kurfurst, 2015; Kürten, 2008; Labbé \& Boudreau, 2011).

One of the most relevant studies on Vietnamese public space is Kim's (2O12, 2015a,b) work on the streets of Ho Chi Minh City. Her investigation analyses the everyday making of public spaces and is the first to substantially address bottom-up processes of spatial production in the Vietnamese context. Her description of peculiar mixed-use sidewalk conditions illustrates how the plural, multi-layered and divergent uses of shared space integrate time into the analysis of physical places. Kim sees the sidewalk as a discrete space, a container with a certain degree of autonomy that houses everyday practices with fleeting territorial boundaries. Also, the study of Lisa Drummond (2000) and Sarah Turner (2009) and Laura Schoenberger (2012) on Vietnamese urban life is of great importance for the understanding of the relationship between public and private space at everyday level. She describes how, in the city of Hanoi, the vibrant street life has to do with a peculiar form of blurring of the boundaries between inside and outside the private realms. Her research, however, is focused on social transformations and only marginally considers architecture and design aspects.

Studies analysing space as a constitutive factor of the amalgamated informal territorialities that include the interspatial relations between private and public space in Vietnam are very limited. The way in which Hanoi's Ancient Quarter's sidewalks developed a transient, floating space that defeats any rigorous and fixed prescription, enacting a dynamic, variable, transformative and "messy" realm has still to be investigated thoroughly.

\section{The Urban Development of the Ancient Quarter}

Hanoi was chosen as the capital by King Ly Thai To in 1010. As the legend goes, when the King went to Dai La Citadel (the formal name of Hanoi), he saw a rising dragon and decided to assign a new name to both the citadel and the city: Thang Long - the Ascending Dragon. In the feudal period, the city consisted of two parts: The Royal City and The Commoner's City (Hoang \& Nishimura, 1990). The Ancient Quarter originated from the latter (Hoang \& Nishimura, 1990), and is situated next to the Red River - the main stream of the Gulf of Tonkin (Fig. 2). The position of the district, between the river and the citadel, triggered the commercial development. There, traders from neighbouring villages gathered and stored up their goods and products for the Royal City. Also, the old name of Hanoi, Ke Cho - a marketplace recognises its primary trading role. From the fifteenth to the beginning of the eighteenth century, there was little change in the plan of the Commoner's City (Hoang \& Nishimura, 1990). 
The first description of the Commoner's City's 36 old streets dates back to 1464, during the Le dynasty (Hoang \& Nishimura, 1990). Each street was named either indicating the products of household clusters or referring to distinctive local features (Hoang \& Nishimura, 1990). In 1802, Nguyen Anh, who established the Nguyen dynasty, chose Hue as the new capital and geared it with a new Royal City (Hoang \& Nishimura, 1990; Le, Nga, \& Anh, 2011). This only resulted in the decay of Hanoi's Royal City (Hoang \& Nishimura, 1990; Ministry of Construction [MoC], 1999), since the Commoner's City maintained and further developed its role as a prime marketplace (Hoang \& Nishimura, 1990; MoC, 1999).
Fig. 2 Hanoi in 1873. Source: Ancient Quarter Management Board.

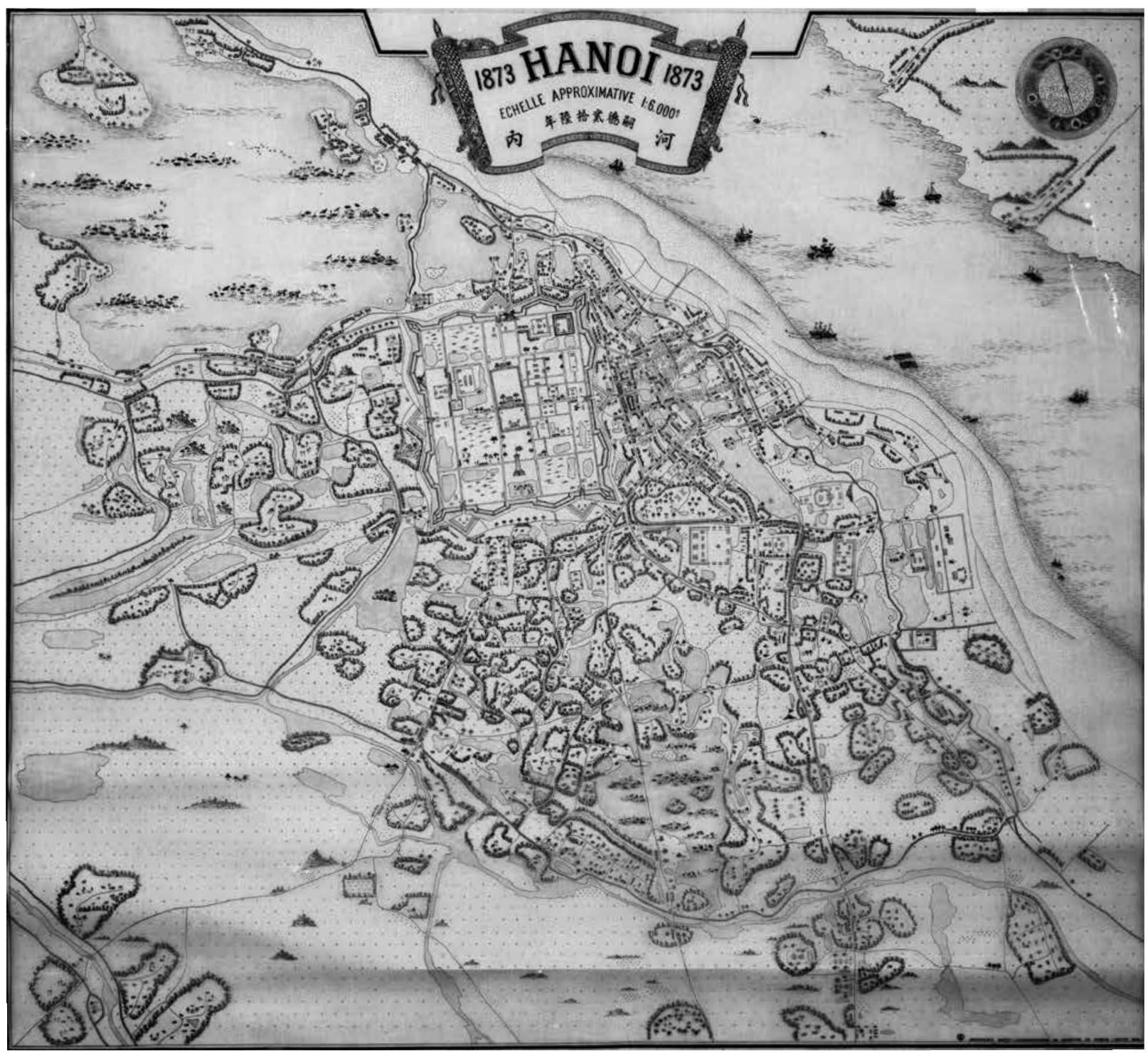



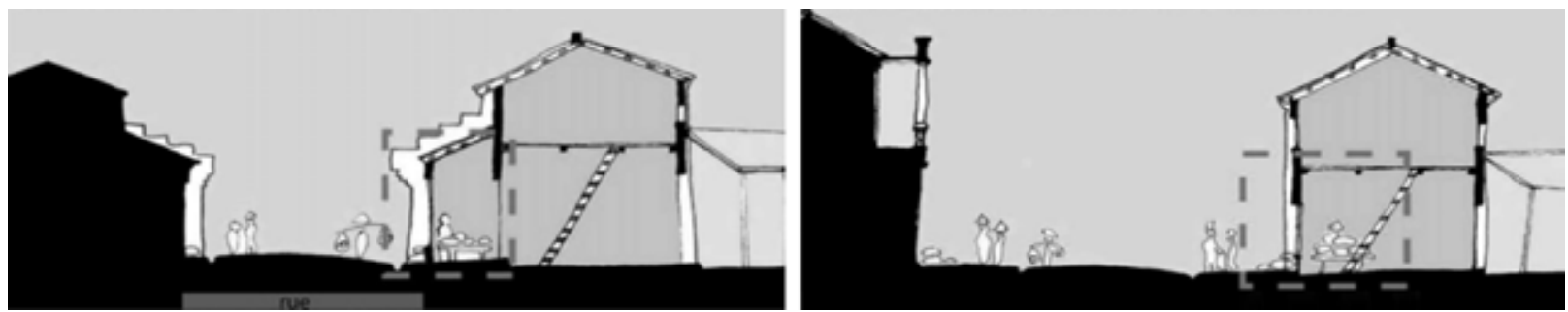

Fig. 3 Typical street section before (left) and after (right) the transformations during the French colonial period (1873-1954). Source: Hanoi 2010 -Heritage \& Cultural Identity (The Asia URBS Programme).

During the French colonial period (1873-1945), Hanoi urban structure underwent a significant change. The whole city was reconfigured; many Vietnamese buildings were demolished to strengthen the Western image (MoC, 1999). A major addition, with typical colonial grid structure, was formed in the French concession located south of the city. The 36 old street area had noticeable transformations: streets were improved with the addition of sidewalks, lighting and drainage; markets were reorganised and provided with dedicated venues (Nguyen, 2015). The creation of sidewalks was achieved with the introduction of substantial clearance policies. These imposed the removal of traditional building extensions intended for conducting business activities (Le, Duong, \& Tran, 2011; see Fig. 3).

After the first Indochina War (1946-1954), many inhabitants of the ancient district rapidly moved to South Vietnam (Hoang \& Nishimura, 1990). The abandoned buildings were distributed to returning Vietnamese soldiers who had lost their houses. Many family houses were split into small units and become collective residential buildings for up to four households (Loan, 2004). This constituted a triggering factor for the district overcrowding. During the following subsidy period, all business activities were banned, and the quarter became merely residential (Le et al., 2011). Only in 1986, the "Doi moi" (renovation) policy which reintroduced forms of market economy, triggered the district flourishing revival of household business practices that, to date, includes more than 5,000 activities. (Le et al., 2011). During this period of economic revitalisation the district increased its density (Fig. 4) and residential overcrowding, with recent estimates reporting a per capita living area ranging from 0.5 to $1.8 \mathrm{~m} 2$ (Loan, 2004). This problem is aggravated by the poor conditions of the building stock of the district: of the approximately 4300 buildings, $63 \%$ have major maintenance problems, $12 \%$ are in a dangerous condition, and $5 \%$ are inhabitable (Loan, 2004). In 2010, the government developed a plan to alleviate the housing crisis, aiming to reduce the population density from 823 to 500 people per hectare by 2020 ( $\mathrm{Tu}, 2015)$. 


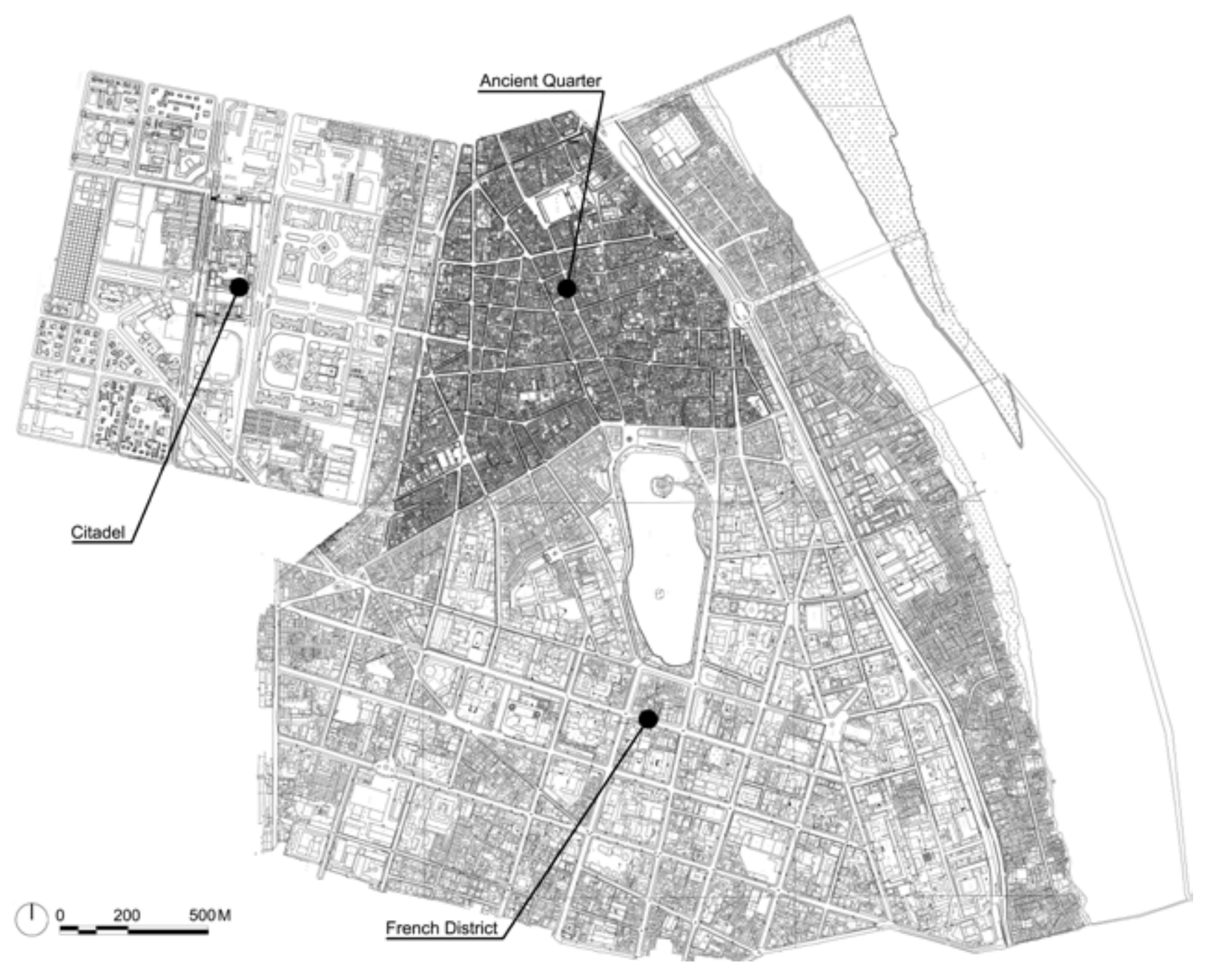

Fig. 4 Plan of Hoan Kiem district and the Citadel. Source: Ancient Quarter Management

\section{The Conceived Public Space in Hanoi}

Board.

Hanoi is a city currently under a profound social, economic and cultural transition. Its population is growing at a rapid pace: it is predicted that from almost 3.2 million in 2005 , the city could reach 4.5 million people in 2020 (Japan International Cooperation Agency [JICA], 2007). Livingconditions are particularly problematic due to the high population density (overall, Hanoi has one of the worlds' highest rates of urban density, up to 404 persons/ha) and a scarce public-space availability (Boudreau et al., 2015) with minimal green areas (park areas account for only $2.6 \mathrm{~km} 2,0.3 \%$ of the total urban area, with some districts showing an average per capita of only $0.05 \mathrm{~m}^{2}$ [JICA, 2007]).

In the early 2000 s, with the aim of supporting the socio-economic growth of the city, the Vietnamese government formulated a series of strategies to transform Hanoi into a creative city. These strategies were implemented with "public order" policies that included public space improvements, such as sidewalk clearance, and a crack-down 
on informal occupation practices (Kim, 2012, 2015b). Its aim was reiterated in 2008 with a policy $(\mathrm{PCH}, 2008)$ established to ban street vendors and obtain clean and efficient streets (Geertman, 2010; Turner \& Schoenberger, 2012). Enacted in July 2008, this policy declared street vendors' activities obsolete and non-productive, as well as a traffic hazard, and banned them from 63 streets of the central district and public spaces around historical sites, official buildings, hospitals, schools, and bus and train stations. The chairman of the Hanoi People's Committee explicitly declared his commitment to develop the capital into a more civilized and modern place (VOV, 2008), stating: "we need to clear people off the sidewalks for the sake of traffic congestion and public health, and in order to be a modern, world-class city" (Kim, 2015b: 3).

In 2009, to address the problems of the district regarding food safety, disorder of traditional markets, dysfunction of retail organisation and lack of competitiveness with the new shopping complexes the Committee proposed a ten-year plan to develop and modernize the current system of the city's markets (Geertman, 2010). According to the plan, no new market should be built in any of the four old districts (Hoan Kiem, Ba Dinh, Dong Da, and Hai Ba Trung) and only important old markets allowed to be upgraded or replaced (Geertman, 2010). To date, the renovated markets have failed to attract traders as well as consumers (Duc, 2014; Geertman, 2010; Long, 2014), while traditional markets remain the major distribution channel of both grocery products and general merchandise (Maruyama \& Trung, 2007), they have triggered the growth of distributed informal markets with fresh produce (DucTinh, 2012). Although traditional markets are considered a hindrance to economic development (Drummond, 2000), consumers of all social groups choose them for fresh food provision (Maruyama \& Trung, 2007). Statistics from the Ministry of Trade show that in 2004 more than $90 \%$ of all products were distributed by traditional channels (VNS, 2005), which consist of formal markets, informal or frog markets and family convenience stores (Maruyama \& Trung, 2007), and that in $2007,97 \%$ of traditional bazaars were still up and running (Geertman, 2010). The strategy of the authorities to renovate markets and remove informal markets while civilising Hanoi Central city streets has largely failed and the position of traditional integrated-retailers has strengthened.

At the beginning of 2016, the government carried out an experiment to homogenise advertising boards on an important street in Hanoi. The aim of this practice is to introduce a coordinated urban image to be eventually applied to all streets. The dimension, position and even the colour of advertising boards are pre-determined to control the appearance of street frontages. Moreover, to set off the city's historical centre, some important streets are being turned into pedestrian areas during weekends. Although these practices might help improving management of the city, they often encounter opposition from citizens 
who consider that the imposed regulations limit their individual and collective livelihood and identity.

The quality and form of the spatial instances where grassrootseveryday making of public space resists these policies, thriving at different scales and durations, is one of the foci of the research discussed in this paper. It studies the unique tactics used to encroach on public space in a representative street subject to the abovementioned regulations.

\section{The Lived Urban Street Space ("Inside Out" and "Outside In")}

Overcrowding and the lack of living areas have been identified as driving factors for the peculiar spatial phenomenon concerning street life in Hanoi. Lisa Drummond (2000) and Sandra Kürten (2008) described the cramped living areas of the Ancient Quarter as characterised by forms of ambivalent and temporary territorial transgressions that produce multiple inversions of private and public realms. Drummond coined the terms "inside out" and "outside in" to illustrate such inversions. Inside out concerns the distinctive notion of private space expressed through structured forms of territorialisation of the public space. She contends that the impermanent, yet consolidated and rampant encroachment on public spaces by residents and transients renders these spaces notionally private for their capacity to accommodate activities that are both domestic, such as cooking, dining and working, and commercial, such as the supply food goods and services (Drummond, 2000; Higgs, 2003; Kürten, 2008). Outside in refers to a reversed transgression of borders operated by the state in the attempt to reinforce domestic identity, through the promotion of family culture and "appropriate" organisation of private life, both in productive and reproductive fields.

The peculiar character of these urban environments in their perpetual public/private transition is their mix of use: on main streets, hybrid combinations of commercial and residential activities are common. Building sections that face directly onto streets are of utmost importance in this process, and their prices are much higher compared to the inner ones. There, often, small-scale commercial businesses are combined with residential space and have their publicness continuously redefined, both socially and physically.

The forms of appropriation of public space are not a specific phenomenon of this area, but widely diffused in Vietnamese cities and towns. They reflect the inborn habit of local people of integrating living and trading spaces and expanding them into the collective realm. They have a fundamental role in the development of the social environment, providing effective relational platforms. Yet, if appropriations are of conflictual nature, they are always grounded in complex dynamics of cohesive communities. They act as open systems that also favour the inclusion of migrants and transients, always through processes of collective negotiation. They are key in providing social empowerment 

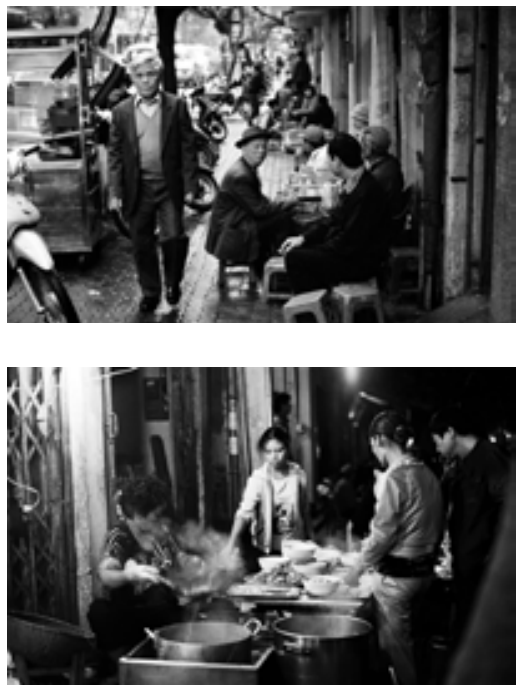

Fig. 5, 6 Contested sidewalks in Hanoi Ancient Quarter: An errant pedestrian negotiating his path among resident lounges, mobile retail stalls and scooter parkin (left). Pho (noodle soup) Quầy vỉa hè (right). ( $)$ Duc Tran.

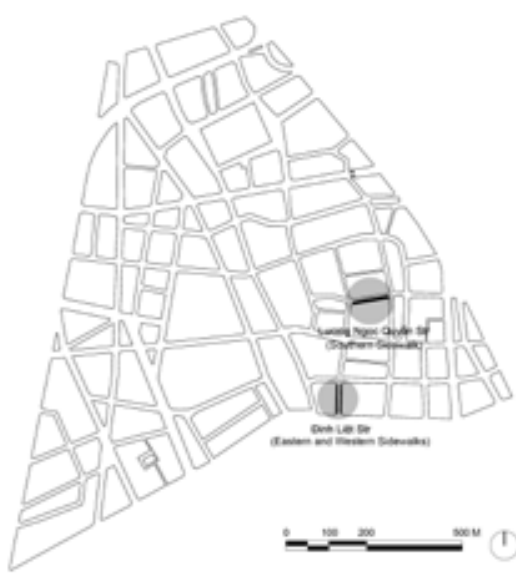

Fig. 7 Map of the Ancient Quarter with indication of Luong Ngoc Quyen and Dinh Liet streets. both on individual and collective levels, strengthening identity, interpersonal bonds and attachment to place, and eventually fostering a sense of autonomy and freedom of expression (Fig. 5, 6).

\section{Luong Ngoc Quyen and Dinh Liet's Streets as Case Study} The part of Luong Ngoc Quyen's and Dinh Liet's sidewalks (Fig. 7) chosen as case studies are two streets among twenty that retain the most traditional, historical, structural and social features of Hanoi's central district. These streets are currently included in redevelopment plans actuating the above-mentioned renovation policies. They were selected also because both are situated on the boundary between two wards - the lowest level of the state's administration (respectively Dong Xuan and Hang Buom, and Hang Bac and Hang Dao). Their position is strategic in attracting street vendors, since informal, itinerant-street vendors tend to operate along the borders of wards to avoid police control (Turner \& Schoenberger, 2012). As such, the streets integrate the multifarious grassroots activities and events generated by local inhabitants with the ones introduced by transients.

\section{Research Methodology}

\subsection{Spatiality analysis articulation}

The contested nature of the sidewalk results from a complex collaborative-agonistic relation between multiple actors in their everyday struggle for persistence. Variable relations of alliance and conflict develop on a field of contrasting forces of autonomy and control, both internal to the community and between it and the pertinent governmental authorities. The nature of these relationships is at the base of socio-spatial differentiation and homogenisation processes that have been conceptualised by Lefebvre (1991) as characterizing two opposing kinds of space: the "abstract" and the "differential." Despite their conflictual nature, they are consubstantial forces contributing to the production of social space.

"Abstract space" determines a condition tending to socio-spatial fragmentation. It encompasses the factors steering the dominant consumption-driven society and the "world of commodities" (p. 53) following what David Harvey (2000) defines as the imperative logics of capital reproduction. Such space, Lefebvre argued, harbours specific contradictions leading to the emergence of its counter-space - the "differential space." This is a condition that privileges autonomy, inclusiveness and social interplay, yet exposes ambiguity and difference. By embracing contradictions and conflicts, it catalyses emerging trends of reconstitution of integrity in social relations, social meaning, and collective powers.

The methodology aims to disentangle the complex production of space of Hanoi's street systems and decode the contrast between the abstract and the differential. The former is the space as it formally appears: the space built over time through the accumulation of 
conceptions and implementations of policies and plans, through actions and interaction of all involved agencies. The latter is the space as it is lived and represented through everyday routines and actions. To identify and structure the specific methods, the research elaborates upon Lefebvre's spatial triad (1991) of "spatial practice," "representations of space" and "space of representations." Accordingly, it articulates on two levels (reflecting the abstract and differential orders) the methods for the analysis of these distinctive forms of co-creative urbanism. The levels respectively explore and compare the infrastructural (physical, social and eidetic aspects) and the experienced (territorial aspects) dimensions as summarized in figure 8.

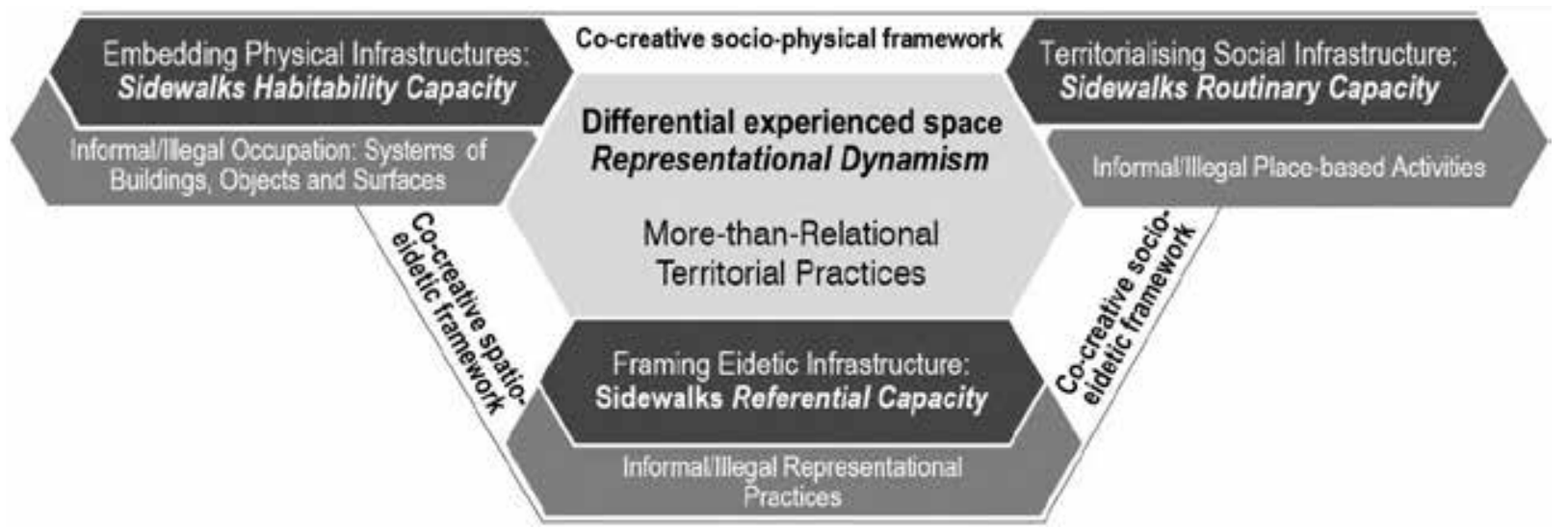

Fig. 8 Diagram of the framework of the multilevel analysis of co-creative infrastructural framework (external sets, in dark grey) and experienced territorialised space (internal set, in light grey).

The investigation of infrastructural configurations, the framework for any spatial event, is articulated in three areas, addressing the physical, socio-spatial and spatio-eidetic attributes. The physical attributes supporting public-space inhabitation are evaluated assessing accessibility, usability, configuration, grain, materiality, permeability and visual pellucidity of open spaces, buildings, vertical and horizontal interfaces and objects, focusing on their permanence and variability over time. The investigation of socio-spatial characteristics supporting routinary practices assesses nodes and networks of place-based productive, commercial, civic, social, recreational and semi- and para-domestic activities, considering their profusion, diversity, redundancy, anchoring, civilness and eventfulness. The study of eidetic properties evaluates the quality of images and underpinning cognitive referentiality, focusing on indexical, symbolic and iconic values, distinctiveness, legibility, iconicity, typo-morphological character and decorativeness. 
The differential agency of experienced spatialities scrutinizes both the perceived and representational dimensions. It focuses on relational activities and territorialities of individuals and related actors and networks of each distinct "urban ecology." Considering time as a key variable, this investigation area seeks to interpret spatialized practices and actions. Exploring their relations to configurations, organisations and representations endowed with cultural and social meanings, it evaluates how spaces are appropriated, produced and represented by both resident and transient inhabitants.

\subsection{Spatial ethnography and mapping methodology}

Ethnographic studies substantively contribute to this investigation, providing analytical instruments to decipher and interpret social relations and meanings underneath the tangled practice of everyday sidewalk life (Brewer, 2000). It informs the adoption of everyday performative mapping methods, providing a critical approach to the identification of attributes concerning the role of space in people's lives (Crampton \& Krygier, 2006). The theoretical and applied work of Annette Miae Kim (2012, 2015a, 2015b) provides a useful lens to connect the social realm with the physical-spatial realm, proposing a spatial-ethnography method that effectively combines physicalspatial analysis and ethnography. Her work on a peculiar economiclivelihood regime in Asian contexts also operates a critical integration of actor-network theory elements with property rights and territoriality approaches to interpret the complex relations between state law enforcements and citizens' resistance forms.

Relevant references are also found in the work of Doreen Massey and James Defilippis. Massey (1994) describes how spatial and gendered relationships are not static, but always dynamic. Her research reveals how social-spatial relations cannot be seen from either the mere surface of the materiality of the city or the preconceived notion of how the city works. Defilippis (1997) argues that the asserted "end of public space" is derived from a reductionist consideration of social relations as "the by-product" (p. 406) of spatiality. He maintains that, instead of dissolution, public spaces are being profoundly transformed by a concomitant reorganization of spatial structure, built materiality, spatial meaning, and space-based relationalities.

\subsubsection{Territoriality and cartography}

The multi-layered way people of the Ancient Quarter use space to appropriate and communicate ownership or occupancy of areas, animates the conflict between the two forces of production of abstract and differential space. This conflict reframes, every day, the negotiated informal territorialities on sidewalks through the multimodal tactics enacted by people to claim their territories. To study them, this research borrows Mattias Kärrholm's (2007, 2016) interpretation of territorial-power relations as the main agency in the establishment 
control over related sequences of discrete spatialities. Territories are seen as "spatial actants" that host specific networks and remain effective through continuous production and reproduction of fields and borders. The interrelations among them produces territorial systems in steady transformation that, in the case of the Hanoian sidewalks, is extremely instable and subject to swift variations. To disentangle the clusters of social and spatial relationality, cartography plays a key role, since it provides validated methods to collect and analyse both qualitative and quantitative data collected through fieldwork, with observations, interviews and visual recordings (static and dynamic). This enables a process of map making that, as Kim (2015a, 2015b) argues, is complementary to the prevailing process of map making, including testimony and visionary maps that reflect the dominance of elites' visions. In other words, it opposes the top-down perspectives that fail to capture what is really happening out there, with forms of mapping that record social-spatial relationality operated by regular citizens.

\section{Preliminary Findings}

\subsection{Actors/practices}

A preliminary evaluation of the life on sidewalks was done with a survey on Luong Ngoc Quyen and Dinh Liet streets in September 2016 on two consecutive weekdays and a weekend. The sidewalks were observed and documented with photos and videos at three relevant times of the morning (6-7 a.m.), afternoon (5-6 p.m.) and evening (8-9 p.m.). Annotations were taken with notes and sketches.

Results show that six actors are the main contributors to the everyday life of the sidewalk, each operating a distinct strategy and tactic. They are ward officials, store owners, mobile street hawkers/ vendors, local residents living in spaces connected to the shops or inside the block (in units not facing the streets), transient pedestrians and a distinctive actor: the Quầy vỉa hè (Fig. 9, 10).

\subsection{1. [(Pre) Over-determined spatialities] Control space: The ward official}

Ward officials became primary actors in the early 2000s, when the Vietnamese government introduced a series of sidewalk clearance policies. Police and traffic inspectors now regularly patrol sidewalks and public spaces. Ward officials are responsible for maintaining order on the pavement. They have the mandate to restrict non-pedestrian use of pavement space by residents. Still, ward officials are also influenced by their relationship with residents and their feelings for people who need sidewalk activities to survive (Koh, 2006). They stand in the middle, between the two conflicting demands of the state and the civil society, and try to achieve a balance (Koh, 2006). Koh also emphasizes that the failure of the pavement regime is due to the weak implementation at the ward level. As Benedict Kerkvliet (2001) suggests, Vietnamese statesociety relations are a kind of "dialogue," which implies that the state is
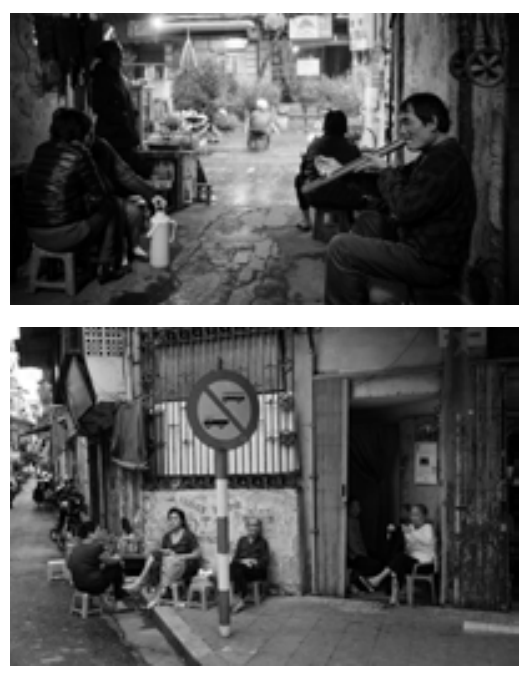

Fig. 9, 10 The tea stands as commons amenity. (c) Quang Duc Tran. 
not all-powerful, but rather both the state and society have an impact on each other in law implementation. The negotiation between the two is clearly seen via the relations between grassroots-everyday practices and ward officials.

In order to take up space on the sidewalk to conduct commercial activities, local residents should have a kind of relationship with ward officials. In fact, they either have a long-term relationship or contribute monthly black income to them as a rent fee for encroaching on the sidewalk. A proprietor informed me that: "If your house is here, you are the only one that might utilize the front sidewalk. However, you just can appropriate the sidewalk for business activities if you have relations with ward's officials." This may explain why many store owners and operators seemingly have the right to use the sidewalk space most of the time.

8.1.2. [Dynamic spatialities] Conducive space: The store owners / Store operators

Store owners and operators tend to consider the front sidewalk as legitimate extensions of their commercial activity, as this habit has lasted for a long time. In the past, the ancient district had little or no pavement, and buildings usually had an extra, pop-up part of the frontage to exhibit household-made goods to save inner spaces for storage and manufacturing processes, and domestic activities. Forms of interspatial expansion developed in the Ancient Quarter for almost a millennium, with various intensity. A shrinkage occurred from 1954 to 1986 , when the city underwent intensive social, political challenges including the resistance war against America. During this period, household businesses were strongly restricted (Le et al., 2011) and tiny informal tea stalls were the most active businesses on sidewalks. Some of them still exist in the streets of our study area, one of them precisely on the north sidewalk of Luong Ngoc Quyen Street. With the Doi moi policy, the ancient district has been given back its role as the commercial hub of Hanoi, and the interspace at the front of stores regains its utmost importance for selling goods and provide services. It is important to note that while the front store is an integral part of the building, it usually constitutes an independent property.

\subsection{3. [Emergent spatialities 1] Compensatory space: The socialised domesticity of the inner resident}

Houses situated in the Ancient Quarter are known as tube-houses, the depth of which varies from 20 to $100 \mathrm{~m}$, with a narrow width ranging from 2 to $4 \mathrm{~m}$ (MoC, 1999; To, 2008), and each of them contains several households. The store owner and his household are thus not the only residents of the building, rather there are different families living behind it. A mutual passage, situated on a side of the house, provides inner residents with access to the street. Although the front store owners see the pavement as part of their shops, due to the cramped 
living spaces the inner residents also make use of this sidewalk for private and business activities. Emmanuel Cerise and Rene de Maximy (2010) suggest such behaviour is commonplace and stands for a traditional lifestyle based on community and neighbourhood. Besides, they argue that things have always been like that in rural villages, as peasants consider the exterior as a part of their living space regardless of whether it is a public space or not.

Some inner residents are easily seen sitting together in front of a mutual passage, leading to inner residential spaces, or at a tea stand, where they play chess, chit-chat or smoke rustic water pipes. The tea stand, as catalyst of their relational activities, also reflects traditional life in rural villages, where it is a common spot, situated right at the village gates, where peasants gather daily to have a break after completing a work shift. The tea stand plays a role as a communal spot - a live channel of the village, and what is happening is probably just a resumption of rural traditions on the sidewalk.

\subsection{4. [Emergent spatiality 2] Relational space: The embedded encounter amenity of the Quầy vỉa hè}

Most tea-stand owners are local residents, and normally the inner inhabitants, as mentioned above. Since the inner residents do not own the front shop, they occupy displaced parts of the sidewalk to open a small stall or Quầy vía hè. By illegally occupying the sidewalk, they provide a wide range of services such as lottery tickets, wooden stamps, fried chicken's wings, noodle soup, sticky rice and motorbike-taxis. They tend to choose the uncertain and disputed sidewalk's spaces, inbetween two front shops, or stand on the intangible line in-between the pavement and the street-space to conduct their business activities.

Some of these inhabitants are retired old citizens, who have been out there on the sidewalk for a long time, and thus local residents accept their activities as an obvious fact. Other Quầy via hè apply negotiation strategies to deal with ward officials or cooperate with stores' owners and operators to have a space on the pavement. There seems to exist a close cycle among these fixed/embedded Quầy via hè as well as between them and the neighbouring stores. For example, a tea stand on the one hand provides tea for people eating at the chickenwing stall next to it, and on the other hand assists in looking after the stall's customer's vehicles. It is also seen that a store leaves part of the front sidewalk for a motorbike-taxi driver who, in exchange helps to supervise buyers' vehicles for the store.

\subsection{5. [Transient spatialities] Itinerant-street vendor}

Itinerant-street vendors, on the other hand, are not local; they are from peri-urban areas (Koh, 2006; Turner \& Schoenberger, 2012). Since the district attracts many visitors, it is an ideal destination for immigrant vendors. Temporarily occupying the sidewalks and the streets seems to be a must for these actors, who are accused of creating traffic 
congestion. Subsequently, they are the main target of the pavement regime and need to keep roaming around, instead of occupying a particular spot, to get away from law enforcement agents (Kim, 2015b). Turner and Schoenberger (2012) report that the itinerant-street vendors occupy the borders of the ward, since ward police do not have the right to punish them outside their territory. Moreover, these movable vendors inform each other about official patrol routines, so that they may avoid police enforcements (Turner \& Schoenberger, 2012). They also are seen standing together in front of the stores or on houses' doorsteps, when shops are closed. As one itinerant vendor shared with me: "I negotiate with the house's residents to stand in front of their frontage when the door is shut. In exchange, I either pay them some money or provide my fresh farming products."

\subsection{6. [Transient spatialities] Accomplice side walker}

Vietnamese people understand that sidewalks are public spaces, and encroachment on these spaces is illegal. Still, they are familiar with these activities and even support them. Twenty of twenty-five interviewees informed us that such activities are colourful, convenient and contribute to a distinct commercial district of the city. They understand that the store and the Quầy via hè have to pay black money to use the sidewalks, therefore they often step down onto streets when facing a congested pavement. Customers even assist shop owners in holding their products when ward officials patrol and confiscate those items scattered on the sidewalk.

\subsection{Tactical service items}

Lightweight materials, either items containing products for sale or the products themselves, are often used to encroach on the sidewalks, to ensure rapid clean-up as police and traffic inspectors patrol. These tactical service items can be categorized into two types: the movable and the fixed.

Movable items are mainly made of light materials, which are easily arrayed and tucked in or moved away as fast as possible. Plastic beer containers, carton, and bamboo sticks are arranged neatly in front of many households' convenience stores - out on the pavements. Also, clusters of colourful plastic stools and umbrellas are scattered around in several pavement cafés and tea stands by the local street traders. The itinerant vendors carry things by pushcart, or yoke and basket, or, on the move, on a motorbike or bicycle.

On the other hand, fixed items are things that are unmovable or already there on streets. They might be holes on electric poles on the sidewalks, in which tea cups and noodle bowls are put. Local residents even nail small tacks/pins, or hooks on tree trunks, standing on the pavement to hang light bulbs, and spread tents once needed. Also, an existing wall is repurposed to attach advertising messages and hang service items. 
All these tiny things contribute to the ambience of the streets, and are pop-up parts of the houses. This seemingly invisible system is the method that local residents apply to make use of outer sidewalks and streets. The buildings' frontage seems to have a peculiar plasticity, where private space is easily stretched out onto the streets, creating the much-needed public realm. This mechanism not only brings about economic value for the locals, and preserves the whole atmosphere of cultural business (traditional commercial activities, traditional customs, vernacular knowledge and experiences in business), but also improves social belonging and mutual support.

\subsection{Fleeting Space/Time on the sidewalk data and map}

The use of the sidewalk varies, and a place can be taken-over again and again by different users and practices during the day. Variations of actors and users over time are recorded and mapped with the identification of users' spatial behaviour and estimate of specific spatial allocations (Fig. 11).
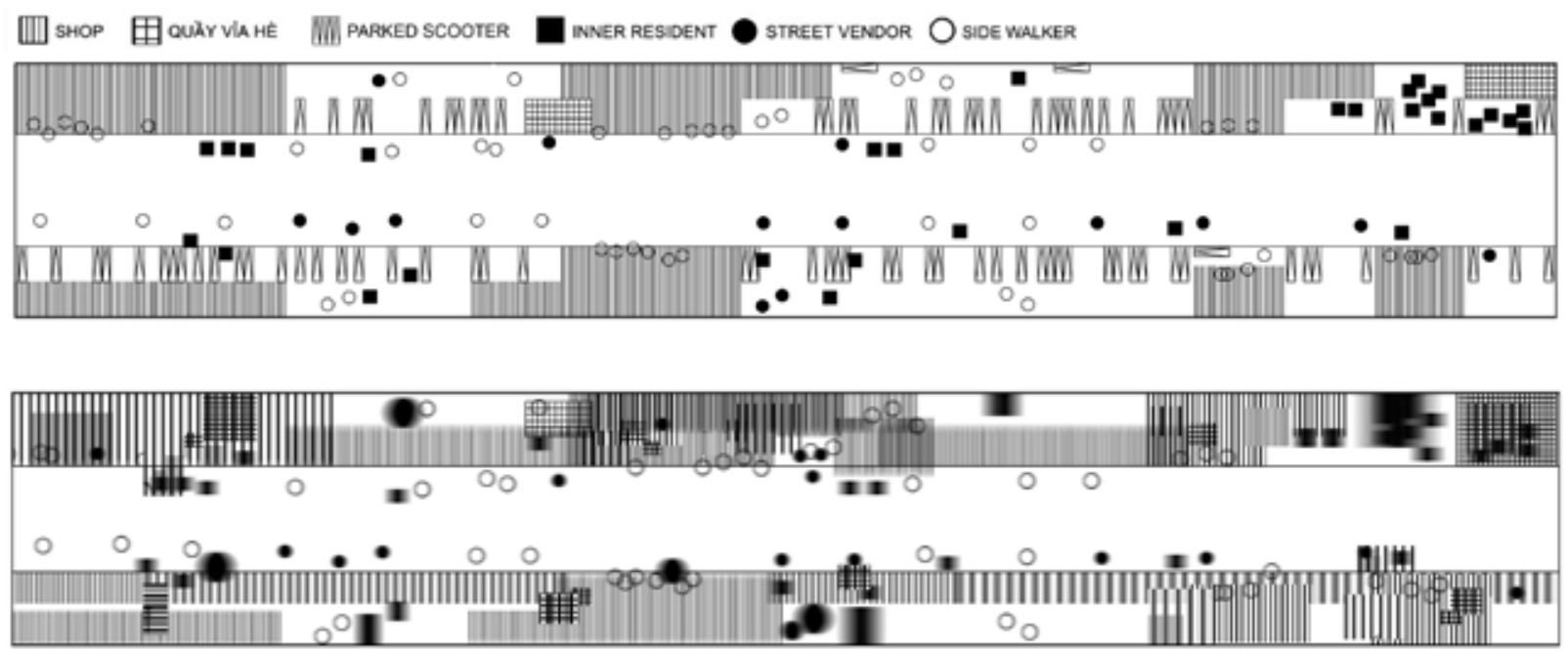

Fig. 11 Dinh Liet Street at 5 p.m. on a workday. Map of sidewalk's land use (top) and of primary territorial sequences (bottom). 
Results of the preliminary survey on Luong Ngoc Quyen Street show that the most congested time of day is from 8 to 9 p.m. with around 132 people present on sidewalks. This is 22 times more than in the morning and almost 5 times more than the afternoon. Concerning age, most of the people belong to the productive age group (160/167). Their gender distribution is balanced (see Table 1). With reference to space occupation, the survey found that in the early morning (from 6 to 7 a.m.) the amount of space devoted to specific functions (i.e., informally occupied by permanent practices of either commercial or domestic nature) registers the least proportion of the day, accounting for around $20 \%$. During this period activities are mainly conducted by itinerantstreet vendors, Quầy Via Hè and inner residents (Fig. 12). In the late afternoon (from 5 to 6 p.m.) and evening (from 8 to 9 p.m.), this ratio rises to around 80 to $95 \%$, respectively. During the late afternoon, stall and store owners, together with inner residents, are dominant users of the space (Fig. 13). From 8 to 9 p.m., stall and store owners pervade the sidewalk (Fig. 14).

Table 1. The number of people/age and gender on Luong Ngoc Quyen sidewalk

\begin{tabular}{|l|c|c|c|c|c|c|}
\hline \multirow{2}{*}{ Time } & \multicolumn{2}{|c|}{ 6-7 a.m. } & \multicolumn{2}{c|}{ 5-6 p.m. } & \multicolumn{2}{c|}{ 8-9 p.m. } \\
\hline Indicators & Male & Female & Male & Female & Male & Female \\
\hline Pre-productive age (<20) & & & & 1 & 2 & 2 \\
\hline Productive age (20-60) & 4 & 2 & 14 & 12 & 67 & 61 \\
\hline Post-productive age (>60) & & & & 2 & & \\
\hline Subtotal & 4 & 2 & 14 & 15 & 69 & 63 \\
\hline Total & \multicolumn{2}{|c|}{6} & & 29 & & 132 \\
\hline
\end{tabular}

Results from the survey on Dinh Liet Street showed a different pattern of occupancy, with the most crowded hours from 11 a.m. to 1 p.m. and 4 to 6 p.m. and a slightly intense use of the sidewalks mainly for activities of stall and store owners (Fig. 15). 
Fig. 12 Sidewalk life from 6-7 a.m. on Luong Ngoc Quyen Street.

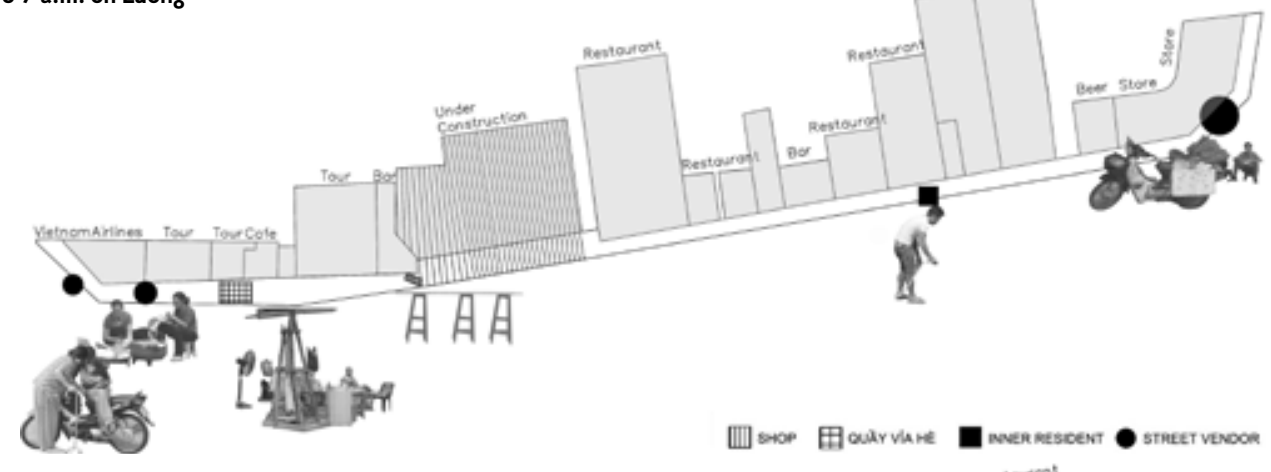

Fig. 13 Sidewalk life from 5-6 p.m. on Luong Ngoc Quyen Street.

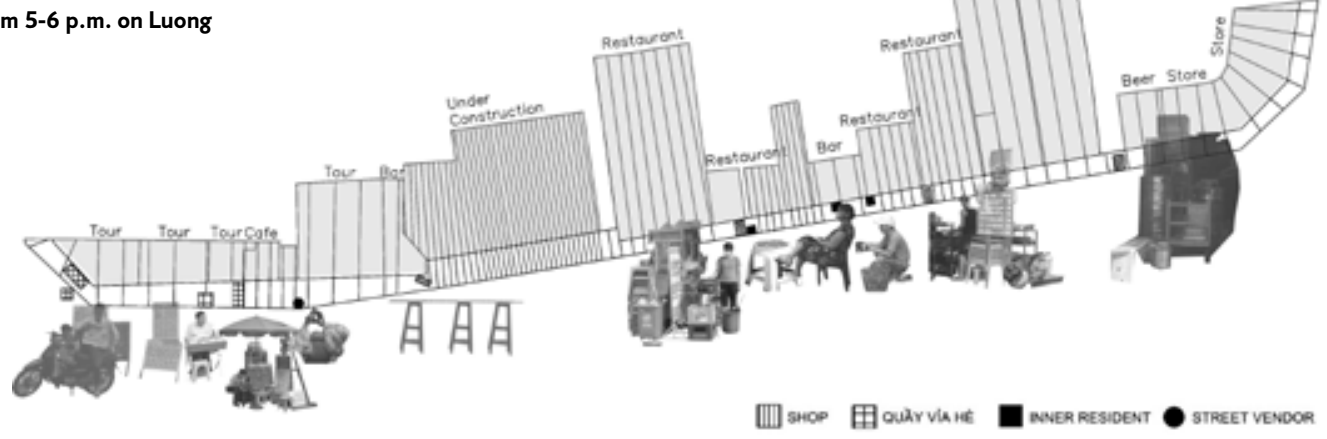

Fig. 14 Sidewalk life from 8-9 p.m. on Luong Ngoc Quyen Street.

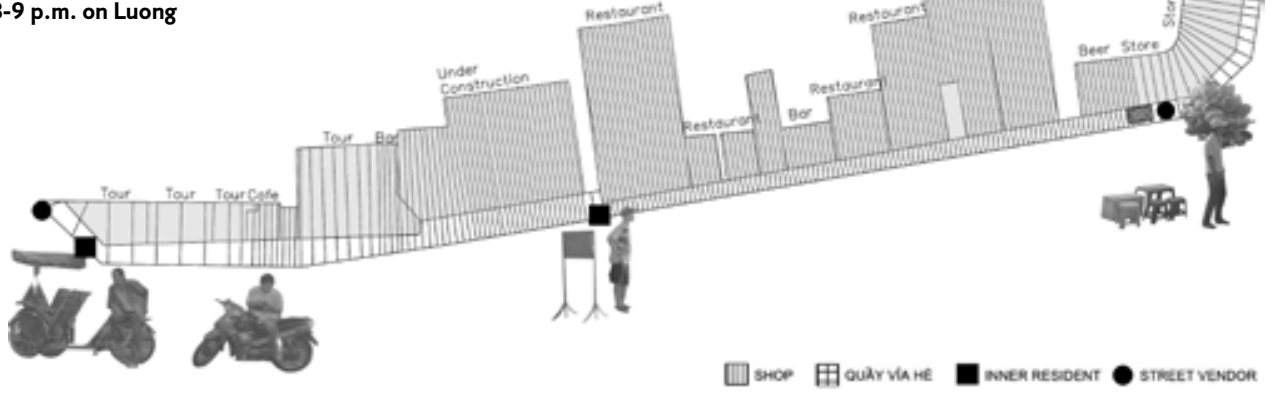

Fig. 15 Dinh Liet Street on a workday. Diagram of sidewalk's occupation over 24 hours.

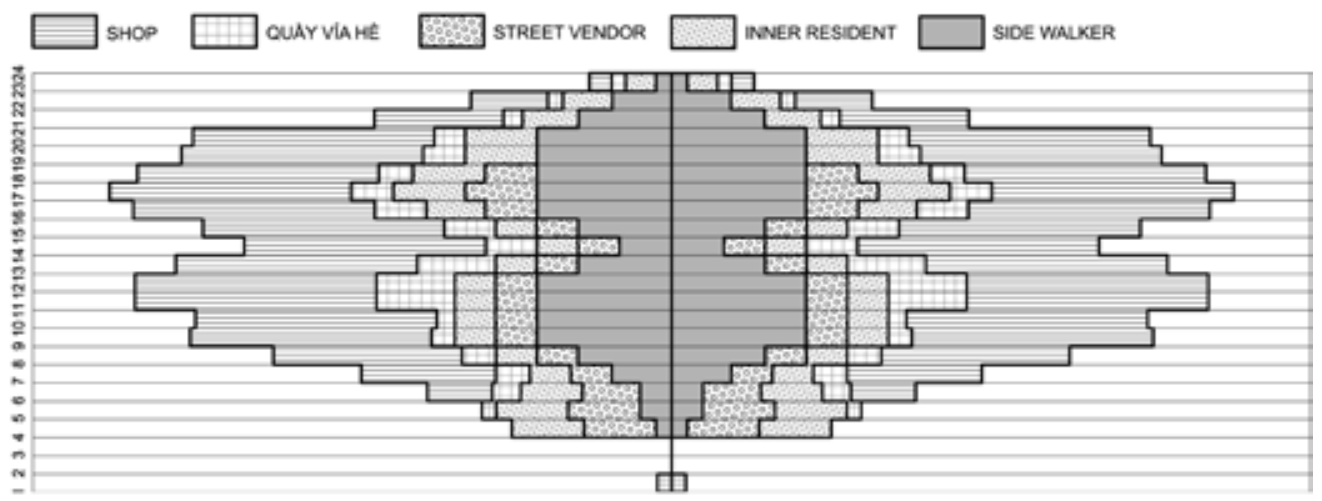




\section{Conclusion: the urban as urgent utopia}

Standing on the 110th floor of a skyscraper, Michel de Certeau (1988, p.92) recognized the conflict between strategy and tactic as he said: "it's hard to be down when you're up." De Certeau used "strategy" to refer to institutions and structures of power, while "tactic" implied an individual acting under that strategy. In the city of tactics, De Certeau put the role of regular citizens upon a pedestal and regarded each individual as a designer, writing the city in a distinctive way different from the overwhelming strategic plan.

The people of the Ancient Quarter have well-chosen tactics to defend their constitutive differential space opposing the top-down abstract space strategies. With their contribution, the resulting city is "as much a consequence of these fluid everyday actions as of the overarching visions of urban designers who conceptualize fixed-in-time master plans" (Kalinski, 1999, p. 105). Our present observations provide an initial interpretation to orient the future study of the mechanism of public-space production in Hanoi Ancient Quarter. The way in which intense and inclusive street life is related to idiosyncratic constructions of spatialities that involve complex networks of local agencies and multiple public-private spatial inversion is explored to understand the complex intertwining of tactics that not only to accommodate the needs of molecular private businesses, but also to integrate complex set of relational practices ranging from food production and services to person, to socialising and cultural exchange.

The research is to ultimately evaluate how this realm is key to produce resistant instances of a kind of space that Hannah Arendt (2013) defined as agonistic - a space in which "moral and political greatness, heroism and pre-eminence are revealed, displayed, shared with others" (Benhabib, 1992, p. 78). This contribution to the research on "micro" aspects of Asian urbanism, such as those on the scale of a tea Quầy via hè, is inspired by a vision of a society where transformations results from "collective ownership and management of space founded on the permanent participation of the 'interested parties', with their multiple, varied and even contradictory interests" (Lefebvre, 1991: 422). 


\section{References}

Arendt, H. (2013). The human condition. Chicago: University of Chicago Press.

-

Barber, B. R. (1998). Democracy at risk: American culture in a global culture. World Policy Journal, 15(2), 29-41.

Baycan, T. (2011). Creative cities: Context and perspectives. In L. F. Girard , T. Baycan, \& P. Nijkamp (Eds.), Sustainable city and creativity: Promoting creative urban initiatives (pp. 15-54). London, England: Ashgate Publishing.
Benhabib, S. (1992). Models of public space: Hannah Arendt, the Liberal Tradition and Jurgen Habermas. In C. Calhoun (Ed.), Habermas and the public sphere. Cambridge, MA: MIT Press.

-

Boudreau, J.-A., Charton, L., Geertman, S., Labbé, D., Hien, P. T., \& Anh, D. N. (2015). Youth-friendly public spaces in Hanoi. Canada: Institute National de la Recherche Scientifique. Retrieved from http://www. hanoiyouthpublicspace.com
Brenner, N., Marcuse, P., \& Mayer, M. (Eds). (2012). Cities for people, not for profit: Critical urban theory and the right to the city. New York, NY: Routledge.

-

Brewer, J. (2000). Ethnography. Philadelphia, PA: Open University Press.

Cerise, E., \& de Maximy, R. (2010). Road system and urban recomposition in Hanoi. In P. Gubry, F. Castiglioni, J.-M. Cusset, N. T. Thieng \& P. T. Huong (Eds.), The Vietnamese City in Transition (pp. 33-62). Singapore: Institute of Southeast Asian Studies. 
Cooke, P. N., \& Lazzeretti, L. (Eds). (2008). Creative cities, cultural clusters and local economic development. Cheltenham, England: Elgar.

Crampton, J. W., \& Krygier, J. (2005). An introduction to critical cartography. ACME: An International E-Journal for Critical Geographies, 4(1), 11-33.

de Certeau, M. (1988). The practice of everyday life (S. Rendall, Trans.). Berkeley: University of California Press.

de Chazal, J. (2010). A systems approach to livability and sustainability: Defining terms and mapping relationships to link desires with ecological opportunities and constraints. Systems Research and Behavioral Science, 27, 585-597.

-

Davis, M. (1992). Fortress Los Angeles: The militarization of urban space. In M. Sorkin (Ed.), Variations on a theme park: The new American city and the end of public space. New York, NY: Hill and Wang.

Deleuze, G., \& Guattari, F. (1977). Anti-Oedipus: Capitalism and schizophrenia. Minneapolis: University of Minnesota Press.

Defilippis, J. (1997). From a public reĐcreation to private recreation: The transformation of public space in South Street Seaport. Journal of Urban Affairs, 19(4), 405-417.

Drummond, L. B. (2000). Street scenes: Practices of public and private space in urban Vietnam. Urban Studies, 37(12), 2377-2391.

Douglass, M., \& Huang, L. (2007). Globalizing the city in Southeast Asia: Utopia on the urban edge the case of Phu My Hung, Saigon. IJAPS, 3(2), 1-42.

Duc. (2014). Trung tâm thương mâi đìu hiu và nỗi buồn mất chợ truyền thống [Press release]. Retrieved from http://vov.vn/kinh-te/trung-tamthuong-mai-diu-hiu-va-noi-buon-mat-cho-truyenthong-352349.vov\#

DucTinh. (2012). Bỏ hoang chợ hiện đại, dân tìm về chợ cóc [Press release]. Retrieved from http:// kienviet.net/2012/07/18/bo-hoang-cho-hien-daidan-tim-ve-cho-coc

Economist Intelligence Unit. (2016). Global liveability ranking 2016. Retrieved from http:// www.eiu.com/

-

Evans, G. (2003). HardĐbranding the cultural cityfrom Prado to Prada. International Journal of Urban and Regional Research, 27(2), 417-440.

-

Florida, R. (2014). The rise of the creative class, revisited. New York, NY: Basic Books.
Franck, K. A., \& Stevens, Q. (2007). Tying down loose space. In K. A. Franck \& Q. Stevens (Eds.), Loose space possibility and diversity in urban life (pp. 1-33). New York, NY: Routledge.

Geertman, S. (2010). Fresh market, a way of life and public health under threat: Experiences in Europe and Asia and action for Hanoi. HealthBridge Liveable Cities Program, 1-10.

Geertman, S., \& Le, Q. C. (2010). The globalization of urban forms in Hanoi. Retrieved from http:// www2.unine.ch/files/content/sites/inst_geographie/ files/shared/documents/hanoi_ouaga/2_The_ Globalisation_Urban_Form_in_Hanoi_second_part. pdf

City of Hanoi, City of Toulouse, Brussels Capital Region (2006). Hanoi 2010 - Heritage \& Cultural Identity, unpublished report. Hanoi, Vietnam: City of Hanoi.

-

Harvey, D. (2000). Spaces of hope (Vol. 7). Berkeley and Los Angeles, CA: University of California Press.

$-$

Harvey, D. (2005). The political economy of public space. In S. Low \& N. Smith (Eds), The politics of public space (pp. 17-34). New York, NY: Routledge.

-

Higgs, P. (2003). Footpath traders in a Hanoi neighbourhood. In L. B. Drummond \& M. Thomas (Eds.), Consuming urban culture in contemporary Vietnam (pp. 75-87). London, England: Routledge.

-

Ho, K. C., \& Douglass, M. (2008). Globalisation and liveable cities: Experiences in place-making in Pacific Asia. International Development Planning Review, 30(3), 199-213.

Hoang, H. P., \& Nishimura, Y. (1990). The historical environment and housing conditions in the " 36 Old Streets" Quarter of Hanoi. Bangkok, Thailand: Division of Human Settlements Development, Asian Institute of Technology.

-

Hodkinson, S. (2012). The new urban enclosures. City, 16(5), 500-518.

Hornidge, A. K., \& Kurfürst, S. (2010). Envisioning the future, conceptualising public space: Hanoi and Singapore negotiating spaces for negotiation (No. 58). ZEF Working Paper Series.

-

Hutton, T. A. (2015). Cities and the cultural economy. New York, NY: Routledge.

-

Japan International Cooperation Agency. (2007)

The comprehensive urban development programme in Hanoi, capital city of the Socialist Republic of Vietnam (HAIDEP). Retrieved from http://open_jicareport. jica.go.jp/pdf/11856093_01.pdf
Kalinski, J. (1999). The present city and the practice of city design. In J. Chase, M. Crawford, \& J. Kalinski (Eds.), Everyday urbanism (pp. 88-109). New York, NY: The Monacelli Press.

Kärrholm, M. (2007). The materiality of territorial production. Space and Culture, 10(4), 437-453. doi10.1177/1206331207304356.

Kärrholm, M. (2016). Retailising space: Architecture, retail and the territorialisation of public space. New York, NY: Routledge.

$-$

Kerkvliet, B. J. (2001). An approach for analysing state-society relations in Vietnam. Journal of Social Issues in Southeast Asia, 16(2), 238-278.

Kim, A. M. (2012). The mixed-use sidewalk: Vending and property rights in public space. Journal of the American Planning Association, 78(3), 225-238.

Kim, A. M. (2015a). Critical cartography 2.0: From "participatory mapping" to authored visualizations of power and people. Landscape and Urban Planning, $142,215-225$.

Kim, A. M. (2015b). Sidewalk city: Remapping public space in Ho Chi Minh City. Chicago, IL: University of Chicago Press.

Kitchin, R., \& Dodge, M. (2005). Code and the transduction of space. Annals of the Association of American Geographers, 95(1), 162-180. doi:10.1111/j.1467-8306.2005.00454.x

Kitchin, R., \& Dodge, M. (2011). Code/space: Software and everyday life. Cambridge, MA: MIT Press.

Koh, D. W. H. (2006). Wards of Hanoi. Singapore: ISEAS Publications.

Kürten, S. (2008). The transformation of public space in Hanoi. Asien, 108, 67-79.

Labbé, D., \& Boudreau, J.-A. (2011). Understanding the causes of urban fragmentation in Hanoi: The case of new urban areas. International Development Planning Review, 33(3), 273-291.

-

Landry, C. (2012). The creative city: A toolkit for urban innovators. London, England: Earthscan.

Landry, C., \& Bianchini, F. (1995). The creative city. London, England: Demos.

Lefebvre, H. (1991a). The production of space. Maiden, MA: Blackwell.

Lefebvre, H. (1991b). The critique of everyday life, London, England: Verso. 
Lefebvre, H. (1996). Writings on cities, Oxford, England: Blackwell.

Le, Q. C., Duong, Q. N., \& Tran, D. A. (2011). Nghiên cứu sự biến đổi hình thái, không gian và chức năng thương mại của nhà mặt phố ở khu phố cổ Hà Nội [Research on the transformation of commercial form, function and space of shop-houses in Hanoi Ancient Quarter]. Tạp chí Khoa học Công nghệ [Journal of Science and Technology]. Retrieved from http://bomonquyhoachnuce.edu.vn

Ley, D. (1996). Urban liveability in context. Urban Geography, 11(1), 31-35.

Lim, W. S. W. (2014). Public space today. In W. S. Lim (Ed.), Public space in urban Asia (pp. 20-25). Singapore: World Scientific.

Loan, Đ. (2004). Triển khai nhiều dự án bảo tồn phố cổ Hà Nội [Press release]. Retrieved from http:// vnexpress.net/tin-tuc/thoi-su/trien-khai-nhieu-duan-bao-ton-pho-co-ha-noi-2000923.html

Long. (2014). Ế như trung tâm thương mại [Press release]. Retrieved from http://tuoitre.vn/ tin/kinh-te/20140929/e-nhu-trung-tam-thuongmai/651745.html

Loukaitou-Sideris, A. (1993). Privatisation of public open space: The Los Angeles experience. Town Planning Review, 64(2), 139-167.

Madanipour, A. (1999). Why are the design and development of public spaces significant for cities? Environment and Planning B, 26, 879-892.

Maruyama, M., \& Trung, L. V. (2007). Traditional bazaar or supermarkets: A probit analysis of affluent consumer perceptions in Hanoi. International Review of Retail, Distribution and Consumer Research, 17(3), 233-252.

Massey, D. (1994). Place, space and gender.

Minneapolis: University of Minnesota.

Minton, A. (2012). Ground control: Fear and happiness in the twenty-first-century city. London, England: Penguin.

Mitchell, D. (1995). The end of public space? People's park, definitions of the public, and democracy. Annals of the Association of American Geographers, 85(1), 108-133.

Mitchell, D. (2003). The right to the city: Social justice and the fight for public space. New York, NY: Guilford Press.

Ministry of Construction - Research Institute on Architecture. (1999). Preserving Hanoi's architectural and landscape heritage. Hanoi: Construction Publishing House.
Ngo, T. H. (2006). Đề tài nghiên cứu khoa học 02/RD 02-04: Nghiên cứu hướng dẫn thiết kế đô thị không gian công cộng tại các đô thị lớn VN [Research Project 02/RD 02-04: Research on Urban Design guidelines for urban spaces in Vietnamese Cities].

-

Nguyen, N. T. (2015). Đi xuyên Hà Nội [Go through Hanoi]. Hanoi: Nhà xuất bản trẻ [Youth Publisher].

Pham, T. T. (2002). Tổ chức không gian công cộng trong đơn vị ở đô thị tại Hà Nội [Creating public space in residential units in Hanoi]. (Doctor of Philosophy ), Hanoi Architectural University.

People's Committee of Hanoi (2008) Quyết Định: Ban Hành Quy Định Về Quản Lý Hoạt Động Bán Hàng Rong Trên Địa Bàn Thành Phố Hà Nội [Decision: promulgating regulation on management of street-selling activities in Hanoi]. Decision QDUBND, February.

Popescu, G. (2010). Deterritorialization and reterritorialization. In B. Warf (Ed.), Encyclopedia of geography (pp.722-724). Thousand Oaks, CA: Sage.

Purcell, M. (2013). Possible worlds: Henri Lefebvre and the right to the city. Journal of Urban Affairs, 36(1), 141-154.

Richards, G. (2014). Creativity and tourism in the city. Current Issues in Tourism, 17(2), 119-144.

-

Richards, G., \& Palmer, R. (2010). Eventful cities: Cultural management and urban revitalisation. New York, NY: Routledge.

-

Ruth, M., \& Franklin, R. S. (2014). Livability for all? Conceptual limits and practical implications. Applied Geography, 49, 18-23.

-

Sassen, S. (2011). Cities in a world economy.

Washington, DC: Sage.

-

Scott, A. J. (2006). Creative cities: Conceptual issues and policy questions, Journal of Urban Affairs, 28 , 1-17.

Scott, A. J. (2008). Social economy of the metropolis: Cognitive-cultural capitalism and the global resurgence of cities. Oxford, England: Oxford University Press.

Scott, A. J. (2014). Beyond the creative city:

Cognitive-cultural capitalism and the New

Urbanism. Regional Studies, 48(4), 565-578.

doi10.1080/00343404.2014.891010

-

Sennett, R. (1992). The fall of public man. New York, NY: Norton

Sennett, R. (2006). The open city. Urban Age, 1-5
Staeheli, L. A., \& Mitchell, D. (2006). USA's destiny? Regulating space and creating community in American shopping malls. Urban Studies, 43(5-6), 977-992.

To, K. (2008). Conservation pressing task and new documentation of old tube houses in Hanoi old quarter through the case of no. $47 \mathrm{Hang} B \mathrm{Bac}$ Street house. Journal of Architecture, Planning and Environment Engineering, 624, 457-463.

Tu, L. (2015). Dân phố cổ di dời sẽ được bố trí ở tầng 1 để kinh doanh [Press release]. Retrieved from http://dantri.com.vn/kinh-doanh/danpho-co-di-doi-se-duoc-bo-tri-o-tang-1-de-kinhdoanh-1423770806.htm

Turner, S. (2009). Hanoi's Ancient Quarter Traders: Resilient Livelihoods in a Rapidly Transforming City. Urban studies 46.5-6 (2009): 1203-1221.

-

Turner, S., \& Schoenberger, L. (2012). Street vendor livelihoods and everyday politics in Hanoi, Vietnam: The seeds of a diverse economy? Urban Studies, 49(5), 1027-1044.

VNS. (2005, 1 July). Supermarkets expect fierce competition, Viet Nam News. Retrieved from http:// vietnamnews.vn/economy/144191/supermarketsexpect-fierce-competition.html

VOV. (2008). Building Hanoi into a capital of knowledge-based economics VOV (The Voice of Vietnam).

Wyly, E. (2013). The city of cognitive-cultural capitalism. City, 17(3), 387-394.

Zukin, S. (2009). Naked city: The death and life of authentic urban places. Oxford, England: Oxford University Press. 